\title{
STRATEGIES FOR EFFECTIVE ADAPTATION OF FOREIGN MIGRANTS (THE CASE OF THE OECD MEMBER STATES)
}

\author{
Maria Pitukhina \\ Russian Academy of Sciences, Russia
}

The article deals with the OECD migration policy, namely, its strong points that were revealed during the last 20 years. The author also explains how OECD migration policy responds to technological, economic, and social challenges. In effective adaptation of foreign migrants the principal role is mainly assigned to monitoring of the OECD member states. The outstanding practices of the latter turned out to be highly important for shaping the migration policies of other countries. The article is also dealing with the examples of labor migrants' adaptation to the OECD labor market, particularly, bottleneck vacancies analysis of the Nordic countries, Baltic States, and Central Eastern Europe. Institutions, traditions and employability are extremely important parameters for migrants' adaptation at the new for them labor markets.

Keywords: migrants' adaptation strategies; OECD; migration policy; labor migration; bottleneck vacancies analysis

\section{Introduction}

Migration is a complex and multifaceted phenomenon that affects many spheres of society. As it is highlighted in the World Prospects Report 2015, from 2000 to 2015, the annual net migration to Europe, Northern America and Oceania averaged 2.8 million persons per year.

When countries are grouped by income rather than geography, the attraction of highincome countries is even more evident: from 2000 to 2015, high-income countries received an average of 4.1 million net migrants annually from lower- and middle-income countries. Economic and demographic asymmetries across countries are likely to remain powerful

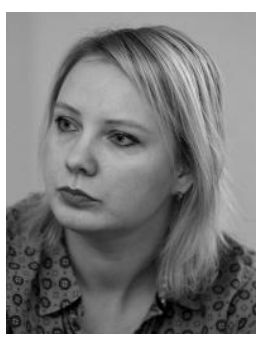

\footnotetext{
Maria Pitukhina

Doctor of Political Science working as a Researcher leader at the Budget monitoring center of Petrozavodsk State University. She is also Professor at the Department of International Relations and Political Science at Petrozavodsk State University as well as the Leading Researcher at the Institute of Economy, Karelian brunch of the Russian Science Academy, Petrozavodsk, Republic of Karelia, Russian Federation.

M. Pitukhina is the author of 3 books on migration policy.

In 2006 Maria got the silver medal from the Ministry of Education and Science of Russia and later became the postdoctoral fellow at Bologna University (August 2010 - June 2011). She defended her Doctoral thesis in Political Science at St. Petersburg State University.
}

E-mail: maria.pitukhina@gmail.com 
generators of international migration within the medium-term future. Large-scale refugee movements have also had a profound influence on the level of net migration experienced by some countries, including those affected recently by the Syrian crisis" (World population prospects, 2015).

At the same time, the World Bank Report pointed out that "global productivity and poverty reduction would accelerate enormously with the free movement of labor. Both recipient states and donor states will benefit from migration"(World Development Report, 2015).

Europe is still one of the most popular destinations with 72 million international migrants living there, data as of 2013 (UN Press Release, 2017). Globally, the largest regional migrant groups are Asians and Latin Americans. In 2013, the Asians became the largest migrant group, with $19 \mathrm{mln}$ of them living in Europe alone (UN Press Release, 2017). International migration is also characterized by high concentration although the number of countries involved has significantly increased in the last four decades: in 2013, 10 countries accounted for about half of all international migrants. The USA was ranked first with 45.8 mln migrants followed by Russia $(11 \mathrm{mln})$, Germany $(9.8 \mathrm{mln})$, the United Kingdom (7.8 $\mathrm{mln}$ ), France (7.4 mln), Spain (6.5 mln) (UN Press Release, 2017).

Taking into account recent huge migration flows across the world, it is highly important to update mechanisms of migration policy regulation following the example of the OECD member states. Their migration regulations make it possible to avoid unbalanced immigration and pursue the most optimal policy. In order to determine the specific directions, their characteristics will be outlined on the examples of Finland, Sweden, Iceland, Canada, Australia, Denmark, the USA alongside with the Baltic States and some of the Central Eastern Europe countries. We will continue with the analysis of migrants' employability, bottleneck vacancies' analysis in Northern Europe, Central Eastern Europe and the Baltic States (Gluschenko \& Ponomaryov, 2009).

Noteworthy, the demand for skills or immigrant labor does not necessarily guarantee easy passage for all migrating people. Employability skills such as literacy and numeracy, technical skills, and good personal skills (integrity, reliability, punctuality, learning capacity) are often in demand. According to employers' surveys carried out by the ILO, the ETF, and Cedefop, "employability skills" rather than "the ability to do work well" are highly crucial for the OECD labor markets.

\section{Methodology}

The research reflects on the data analysis presented mainly on the OECD materials as well as the official documents of the United Nations, the Eurostat, the World Bank and scientific literature. Statistical methods have been used in data processing as applied to vacancies and migrants' unemployment indicators.

In order to scrutinize migrants' specific adaptation features at a new for them labor market as well as prospects of the selected OECD economic sectors in terms of employment and labor market indicators, a functional-structural vacancy analysis was widely applied, taking into account geographical and regional components, the level of vocational education, technological performance of certain economic sectors and employers' qualification requirements to job applicants. 


\section{STRATEGIES FOR EFFECTIVE ADAPTATION OF}

In order to study the employment relations between migrants and resident population in the OECD member-states as well as migrants' employment peculiarities in these countries a systematic approach was applied, with an emphasis on migration growth, institutions regulating labor migration, institutional and social rootedness, best foreign practices, etc. Comparative analysis of employability characteristics in the OECD member states has been also conducted basing on the aggregated indicators developed on the basis of quantitative and qualitative parameters grouped according to expert analysis results.

\section{Regulation of international migration in the OECD member states}

Nowadays global migration policy has been seriously aggravated by notable contradictions. A balance of interests can only be achieved through orienting partners to engage in a mutually beneficial dialogue, so development of various strategies can be well regulated.

In order to get migration policies and regulations closer to equilibrium, the following OECD experiences and tools should be taken into account:

- implementing "integration upon arrival" for all migrants (Finland);

- achieving balance at the labor market (Sweden, Denmark);

- granting a wide range of rights to migrants (Sweden, Finland);

- reducing social tension (Iceland);

- attracting highly skilled and qualified migrants (USA, Germany, Canada, Australia);

- identifying labor shortages by specific job sectors (Australia, Canada, Finland).

The proposed migration regulations can make it possible to prevent unbalanced immigration policy and pursue the most optimal policy in this field. In Finland, active immigration policy is aimed at integrating immigrants through the principle of "integration upon arrival", the essence of which can be described as the following two provisions (Heikkilä \& Pikkarainen, 2011):

- migrants demonstrate willingness to be integrated;

- the host society is also willing to accept migrants.

Thus, Finland makes serious efforts to have migrants learn Finnish language and improve other skills necessary for newcomers. Migrants' children have universal access to education and also the right to be taught in their native language, as in Finland, significant attention is paid to multicultural education. Migrants' access to political participation in Finland is represented by the right to vote and be elected to public offices. The right to join a political party is also exercised at both regional and municipal levels. As a result, back in 2015 already, two first-generation immigrants - N. Razmyar (originally from Afghanistan) and O. Yanar (originally from Turkey) received their mandates to serve in Finnish parliament.

Finland is the second country in the world (after Norway) known for migration policy flexibility. This country has a wide range of laws against racial, religious, and national discrimination. Migrants have free access to legal assistance, and the newly introduced Ombudsman for Minority Rights is acting to protect them. Since January 1, 2015, the Nondiscrimination Act came into force in Finland, according to which a new institution for migrants' rights protection was established - the Ombudsman for the Elimination of Discrimination. At present, there are three special Ombudsmen in the country - the Ombudsman for Equality, the Children's Ombudsman and the Ombudsman for the 
Elimination of Discrimination (Indicators of immigrant integration, 2015). The work of these three institutions is aimed, inter alia, at regulating immigration in this country.

Another regulatory tool used for a better balanced migration policy has been formulated above as "achieving balance at the labor market". Sweden, Finland and Denmark would be especially impressive examples in this regard. Sweden has a very strong orientation towards the inclusion of immigrants. Swedish government provides compensation for the employers hiring immigrants (this is called "social security contribution"). Special attention is also paid to giving migrants professional guidance at early stages of new employment. All materials are provided free of charge for migrants. Specialized online portal provide help with selecting the best educational and professional career path, getting recommendations from career guidance specialists, signing up for various professional guidance activities, Internet testing for professional preferences and finally helping with $\mathrm{CV}$ structuring and contents.

All these activities for immigrants are completely free of charge. Moreover, many employment service managers in Sweden speak the mother tongues of incoming migrants.

Migration policy in Finland is considered to be one of the most effective ones in the world (according to such rankings as the Migrant Integration Policy Index and the Multiculturalism Index). It is highly adaptive and balanced but it is also thoroughly preserving national interests at the same time. Its success is believed to be preconditioned by the following three factors:

1. Well-tuned system of labor market projection parameters.

2. Well-organized system of statistics representing unique and complete data on foreign labor migrants in Finland.

3. Successful human capital development.

Let us analyze these three factors in detail.

1. Well-tuned system of labor market projection parameters in Europe. Finland has designed a truly perfect system for perspective skills monitoring. The key issues solved thanks to labor market parameters' projection are: setting future goals for technological development, education and innovations; determining pros and cons factors influencing the development of the labor market (Occupational Barometer in Finland, 2015).

Projection system in Finland is a complex one, many factors are interrelated in it. Its success can be partially explained by a wide range of participants involved, such as Finnish Parliament Committee, the Ministry of Education and Culture, Finnish National Board on Education, Ministry of Employment and Economy, Statistics of Finland, regional councils, Centers for Economic Development, Transport and the Environment, association of municipal and regional authorities in Finland, universities, research institutes, other social partners.

One of the most useful instruments representing data for all the interested actors is the Occupational Barometer. Both shortage and surplus occupations are calculated for each administrative region of Finland.

2. Well-organized system of statistics is representing unique and complete data on foreign labor migrants in Finland in terms of:

- migrants' employment in the country of origin; Finnish regions' attractiveness for migrants; gender balance in migrants' employment; migrants' employability in various 


\section{STRATEGIES FOR EFFECTIVE ADAPTATION OF}

economic sectors; migration unemployment rate; the share of highly skilled and low-skilled migrants.

Thus, statistics on migrants' employment in a country of origin reveals that the highest level of employment are recorded among the migrants from Estonia, the UK, Sweden, China, Turkey and the USA. Migrants from Iran, Somalia, Iraq and the former Yugoslavia Republic demonstrate the lowest employment rates.

Gender balance in foreign labor migration is quite an interesting issue. Females reveal the same employment results as males - women have been primarily employed in trade $(16 \%)$, education and research (13\%) and healthcare (12\%). These numbers don't seriously differentiate from males' statistics: $17 \%$ have been working in sales, and then $15 \%$-- in finances, insurance and business.

In Finland regions' attractiveness in the framework of foreign labor migration is studied thoroughly (Mankiw et al., 1992). Thus, Finnish Ahvenmaa region is found to offer the most favorable conditions for migrants' employment. The second place goes to Uusimaa region. It is obvious that southern Finland turns out to be the most attractive for migrants as compared to its northern part. Thus, in Lapland, Kainuu only 15\% of migrants are able to find jobs.

3. Successful human capital development. Foreign labor migration influences both current and potential human capital development in a recipient country. Human capital is a complex phenomenon, and one of the ways to evaluate it is by means of the Human Development Index. This is especially important when it comes to performing cross-country analysis, for example. The UN is calculating the Human Development Index on the annual basis. This Index includes such parameters as life expectancy, living standards, literacy, education. In the context of our study it would be interesting to compare countries' parameters and observe how the selected criteria within this index are implemented by the OECD member states and Finland in particular (Pitukhina et al., 2017).

Table 1 below demonstrates native workers' and foreign labor migrants' distribution in Finland in terms of their vocational education level. Balance, the main feature of Finnish vocational system, stands out vividly here, as the levels of education among migrants and native workers are quite comparable. Successful achievement of such a balance became possible due to constant labor force development, besides, it is also supported politically.

Table 1 - Redistribution of native workers and labor migrants in Finland in terms of education level (in \%)

\begin{tabular}{|l|c|c|}
\hline \multicolumn{1}{|c|}{ Level of education } & $\begin{array}{c}\text { Native workers in } \\
\text { Finland }\end{array}$ & $\begin{array}{c}\text { Labor migrants in } \\
\text { Finland }\end{array}$ \\
\hline Tertiary & $37 \%$ & $33 \%$ \\
\hline Secondary & $45 \%$ & $42 \%$ \\
\hline Elementary & $18 \%$ & $25 \%$ \\
\hline Total & $100 \%$ & $100 \%$ \\
\hline
\end{tabular}

In particular, the Finnish National Board of Education has developed a strategy titled "Learning and competence 2020". This document stresses on the development of such skills as creativity, interaction, active participation, self-expression, influence, self-education, responsibility. Together all these skills result in the formation of national intellectual capital. 
Table 2 - HDI qualitative evaluation of foreign labor migrants in Russia and Finland

\begin{tabular}{|l|c|c|}
\hline \multicolumn{1}{|c|}{$\begin{array}{c}\text { Country of origin of } \\
\text { foreign labor migration }\end{array}$} & $\begin{array}{c}\text { HDI of foreign } \\
\text { labor migrants in } \\
\text { Finland }\end{array}$ & $\begin{array}{c}\text { HDI of foreign labor } \\
\text { migrants in Russia }\end{array}$ \\
\hline Germany & 0,905 & \\
\hline Sweden & 0,904 & \\
\hline UK & 0,863 & \\
\hline Estonia & 0,835 & \\
\hline Serbia & 0,766 & \\
\hline Russia & 0,755 & \\
\hline China & 0,687 & \\
\hline Thailand & 0,682 & 0,756 \\
\hline Iraq & 0,573 & 0,745 \\
\hline Somalia & -- & 0,733 \\
\hline Belarus & & 0,729 \\
\hline Kazakhstan & & 0,716 \\
\hline Georgia & & 0,700 \\
\hline Ukraine & & 0,649 \\
\hline Armenia & & 0,641 \\
\hline Azerbaijan & & 0,615 \\
\hline Moldova & & 0,607 \\
\hline Uzbekistan & & \\
\hline Kirgizia & & \\
\hline Tajikistan & & \\
\hline
\end{tabular}

In Finland, the major geographical sources of immigration are very much predictable: nearly $20 \%$ of all labor migrants came from the former Soviet Union republics, the other two major donor countries are immediate neighbors - Sweden (12,8\%) and Estonia (10.3\%).

It is obvious that the countries of migrants' origin are increasingly influencing human capital quality. Thus, taking into account this parameter, the overall Finnish Human Development Index would be amounting to 0,882 as the countries of foreign labor migrants mostly possess very high, high or middle indices (Pitukhina \& Sigova, 2015).

In this regard, it would be interesting to compare the data with Russia: the overall Russian Human Development Index is 0,755 , while foreign labor migrants coming to work in Russia are mostly from the countries with middle and low indices (see Tab. 2 below for more details on this comparison).

Tab. 2 shows that in Finland there is a substitution of natural loss with high Human Development Indices through migration. At the same time, in Russia the situation is just the opposite: natural loss of high HDI is not compensated as foreign labor migrants come from the countries with roughly the same or lower indices. 


\section{STRATEGIES FOR EFFECTIVE ADAPTATION OF}

As a result, migration policy in Finland is considered to be highly adaptive, balanced and first of all preserving national interests and human capital of the country. Success of such migration policy is partially preconditioned by the availability of the best system of labor market parameters' projection in Europe. The projection results of this system are used by both policymakers and ordinary citizens. Having highly detailed statistical data available is also a crucial issue.

Danish immigration policy and its implementation are also of special interest for us. The campaign called "We Need All Youngsters" was launched back in 2003 by the Danish Ministry for Refugees, Immigration and Integration Affairs. It was aimed at fostering equal opportunities in the education system and at the labor market. Since December 2011, the campaign has been transferred to the jurisdiction of the Ministry of Children and Education. The campaign also has a separate and independent branch called the "Retention Caravan". The main objective of these two large-scale campaigns is to improve the integration of young immigrants, including second-generation immigrants, into the labor market by promoting their educational attainment, particularly in the field of vocational education (Russia and EU member states, 2011).

The second objective is to encourage these young students to pursue training in the areas where future shortages are predicted and where young people with migrant background are underrepresented. "We Need All Youngsters" has created a team of young role models with immigrant backgrounds who have been successful in education and/or career. These role models are travelling around the country discussing their experiences with other young people within immigrant communities, giving advice on how to choose and successfully complete education programmes. A team with the title "Parent role models" was also created to share experiences among the parents of these young people.

Recruitment campaigns for various courses in vocational training schools and especially for the courses in social work and healthcare (where shortages in human resources have been forecasted in the near future already) were also launched, targeting primarily immigrant teenagers (16-20 y.o.). A similar campaign was conducted with the aim of recruiting young people for the police, armed forces, emergency and security services. Teachers in vocational training schools have been offered courses to improve their skills in teaching students whose mother tongue is not Danish.

Among its other aims, the Retention Caravan develops new pedagogical tools and methods in collaboration with vocational training schools that are geared towards ethnic minority youth. In response to a shortage of training places and apprenticeships, the Retention Caravan has also developed a user-friendly online guide for students looking for apprenticeships. This guide assists those seeking apprenticeships in writing applications and CVs and helps them perform better during interviews. The Retention Caravan is also recruiting mentor teams among the retired skilled mechanics and blacksmiths to help vulnerable youth during their vocational training courses.

Another tool for a balanced migration policy is providing a wide range of rights for immigrants. Nowadays, there exists the Multiculturalism Policy Index that calculates migrants' rights in various countries.

The Multiculturalism Policy Index is a scholarly research project that monitors the evolution of multiculturalism policies in 21 OECD member states. This project has been launched and implemented by the Queen's University in Canada. The project is designed to provide information on multicultural policies in a standardised format for further 
comparative research and overall better understanding of the state-minorities' relations. The project provides an index for each of the three types of minorities: one index covers immigrant groups; the second one covers historic national minorities; and finally the third one concerns indigenous peoples (Gatman \& Schonberg, 2007). The Index was calculated at three time points - 1980, 2000, 2010 (see Fig. 1 for the latest round).

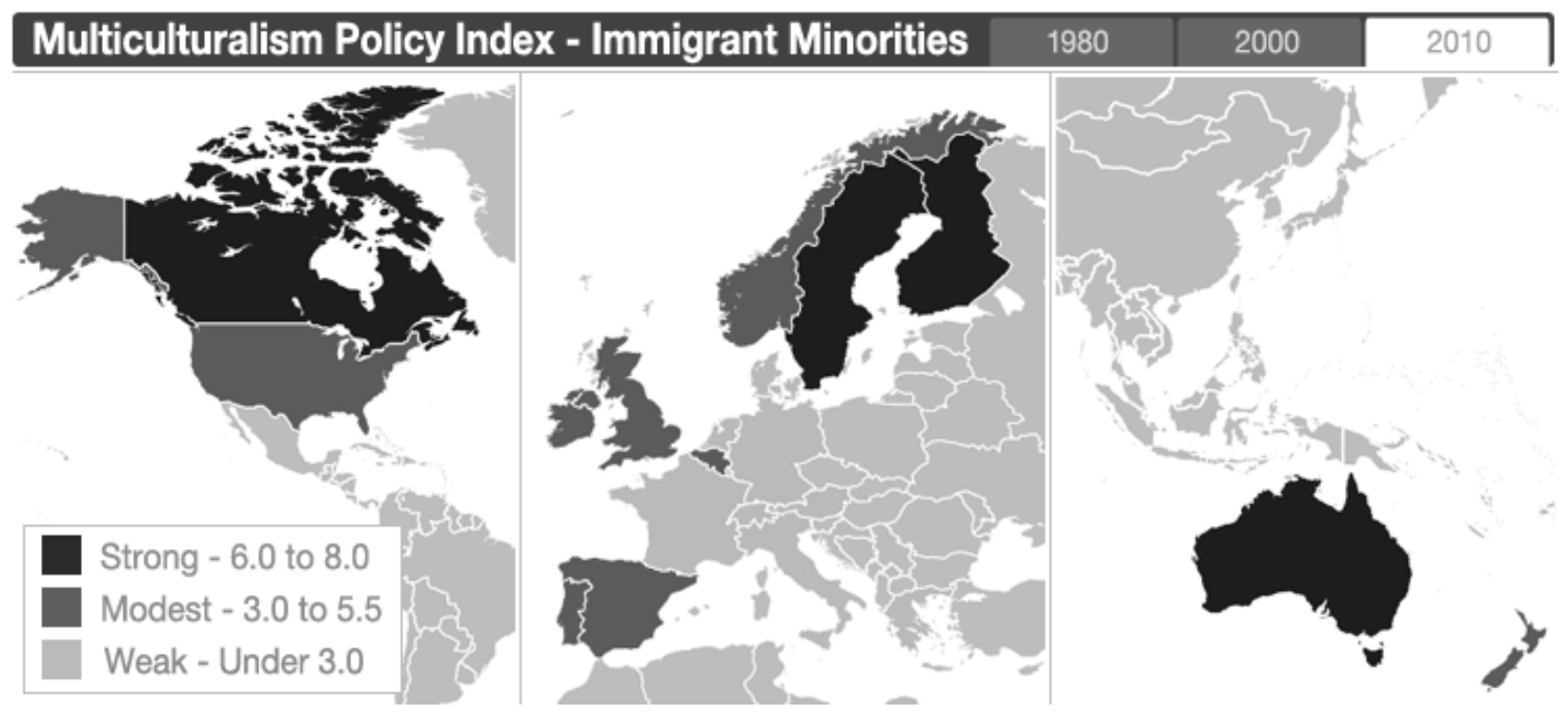

Figure 1 - Multiculturalism Policy Index by Queen's University in Australia, 2010

Thus, the values of the Multiculturalism Index, in part of immigrants in particular, ranges from low level (up to $3.0 \mathrm{pp}$ ) in Italy, France and Germany to medium (3.0 to $5.5 \mathrm{pp}$ ) in the USA, Portugal, Spain, the UK, Norway and then up to high level (6.0 to $8.0 \mathrm{pp}$ ) in Australia, Finland, Sweden and Canada.

In evaluation of multicultural policies related to immigrants, the following eight indicators are used:

- constitutional, legislative or parliamentary affirmation of multiculturalism at the central and/or regional and municipal levels and the existence of a government ministry, secretariat or advisory board to implement this policy in consultation with ethnic minority community;

- the adoption of multiculturalism in school curriculum;

- the inclusion of ethnic representation/sensitivity in the mandate of public media or media licensing;

- exemptions from dress code;

- allowance of dual citizenship;

- funding of ethnic group organisations or activities;

- funding of bilingual education or mother-tongue instruction;

- affirmative action for disadvantaged immigrant groups.

Thus, if a state tries to implement the abovementioned eight criteria, the balance of interests in immigration policy becomes more effective. 


\section{STRATEGIES FOR EFFECTIVE ADAPTATION OF}

In 2010, the highest Multiculturalism Index was recorded in Canada (7.5), Sweden (7), Finland (6), and the United Kingdom (5.5). At present, it can be noted that true multiculturalism has been reached only in Canada, where immigrants form $20.1 \%$ of the total population.

One more area that contributes to equilibrium in immigration policy is seeking to reduce social tensions in society. This parameter can be measured by means of the Social Progress Index, a combined indicator that measures the levels of social well-being and social progress in different countries of the world. The Index was developed in 2013 under the supervision of the world famous M. Porter, Harvard University professor and a specialist in strategic management and international competitiveness.

The Social Development Index is designed to assess social development by the following key criteria: quality of healthcare, level of environmental sustainability, level of tolerance and social inclusion, personal safety issues, nutrition; access to basic medical care; level of education. In 2014, the top five world leaders by the Social Development Index were: Iceland, New Zealand, Switzerland, the Netherlands and Norway. Separate indicators of Iceland, like level of tolerance and social inclusion, are especially impressive.

Recruiting qualified and highly qualified immigrants is another direction in migration policy regulation aimed at improving the balance of national interests. The system of attracting both qualified and highly qualified migrants is not exactly a new idea: in Canada, this system was introduced as early as in 1967. Since then, significant preferences have been given to people younger than 35 years old and those with academic degrees or high-level professional qualifications. In particular, in Canada, $62 \%$ of permanent residence permits are issued on the basis of qualifications; in the USA the share of such permits is $13 \%$ only. However, Canadian merit-based system still faces some criticism, as many occupations of medium complexity are in demand inside the country, while the merit-based system still gives priority to highly qualified personnel primarily.

In what concerns attracting highly skilled and skilled immigrants, American experience with legislative initiatives and employers' initiatives is also of interest:

1. Legislative initiatives. In 2001, the US senators drafted the DREAM Act, which facilitated and accelerated permanent immigration through conditional residency, with the potential for eventual citizenship for young illegal immigrants (under 35) who were brought to the USA as children and who have not committed crimes. They can study at universities or serve in the US Army. In 2012, the senators prepared a draft law that would allow residency permits to those migrants who graduate with a master's degree from an American university or those who have received a degree in the United States.

2. Employers' initiatives. In 2015, M. Zuckerberg, the Facebook founder, donated $\$ 5$ million to the education program for young illegal migrants residing in the San Francisco region: "America was founded as a nation of immigrants. We shall welcome intelligent and hardworking young people of different nationalities in order to help every individual in our society to realize their full potential. With our help, more young migrants will rise by the social elevator to new opportunities, and then our country will make great progress" .

A similar policy in the field of migration regulation is being implemented in Germany. Introduced in August 2012, the system of blue cards enables non-EU citizens to live and work for four years in Germany and other EU countries. Requirements for blue card holders are as follows: university education and knowledge of German language; a labor contract worth an annual income of $€ 46,400$ (€3,867 per month); a labor contract for occupations with 
labor shortage (e.g., scientists, mathematicians, engineers, doctors, computer programmers) with an annual income of $€ 36,192$ ( $€ 3,016$ per month).

\begin{tabular}{|l|l|l|}
\hline Occupation & $\begin{array}{l}\text { ANZSco } \\
\text { code }\end{array}$ & Assessing Authority \\
\hline Construction Project Manager & 133111 & VETASSESS \\
\hline Project Builder & 133112 & VETASSESS \\
\hline Engineering Manager & 133211 & Engineers Australia/AIM \\
\hline Production Manager (Mining) & 133513 & VETASSESS \\
\hline Child Care Centre Manager & 134111 & TRA \\
\hline Medical Administrator & 134211 & VETASSESS \\
\hline Nursing Clinical Director & 134212 & ANMAC \\
\hline Primary Health Organisation Manager & 134213 & VETASSESS \\
\hline Welfare Centre Manager & 134214 & ACWANETASSESS \\
\hline Accountant (General) & 221111 & CPAICAAIPA \\
\hline Management Accountant & 221112 & CPAICAAIPA \\
\hline Taxation Accountant & 221113 & CPAICAAIPA \\
\hline External Auditor & 221213 & CPAICAAIPA \\
\hline Internal Auditor & 22114 & VETASSESS \\
\hline Actuary & VETASSESS \\
\hline & & \\
\hline
\end{tabular}

Figure 2 - The list of deficit occupations in Australia (Source: fragment of Australian Skilled Occupation List, 2015)

Among various tools aimed at reaching the equilibrium in immigration policy, the lists of occupations with labor shortages is of considerable interest. Such lists are widely distributed internationally and help accept migrant workers as "positive" regulators of migration flows (the most famous examples in this regard would be Australia, Canada and Finland).

Unlike quotas, the lists do not set limits but the opposite -- they create preferences. For example, every year the Department of Immigration and Border Protection of Australia forms the list of needed occupations and the skills required for such jobs. Let's take the 2015 list as an example: the Australian Skilled Occupation List of 2015 details 200 occupations that required a minimum level of education equivalent to higher education. Among them were: construction project managers, project builders, engineering managers, production managers, childcare center managers, medical administrators, nursing clinical directors etc. (see Fig. 4 for a fragment of this list).

The government of Canada also annually compiles a list of positions to be potentially filled by migrants - it is called The Canadian Skilled Occupation List. Unlike in Australia, 


\section{STRATEGIES FOR EFFECTIVE ADAPTATION OF}

the Canadian list has only 50 occupations listed; the applicants are also required to have higher vocational education. However, preferences in the Canadian and Australian lists are very similar and mostly focused on attracting highly qualified personnel - human resources managers, purchasing managers, financial managers, senior manages (in trade, business, broadcasting and the like) (see Fig. 3 for a fragment of the Canadian list).

The experience of Finland in this field is also very interesting. Migration regulation closely follows the macroeconomic situation, thus, immigrants are attracted in accordance with a list of positions to be filled.

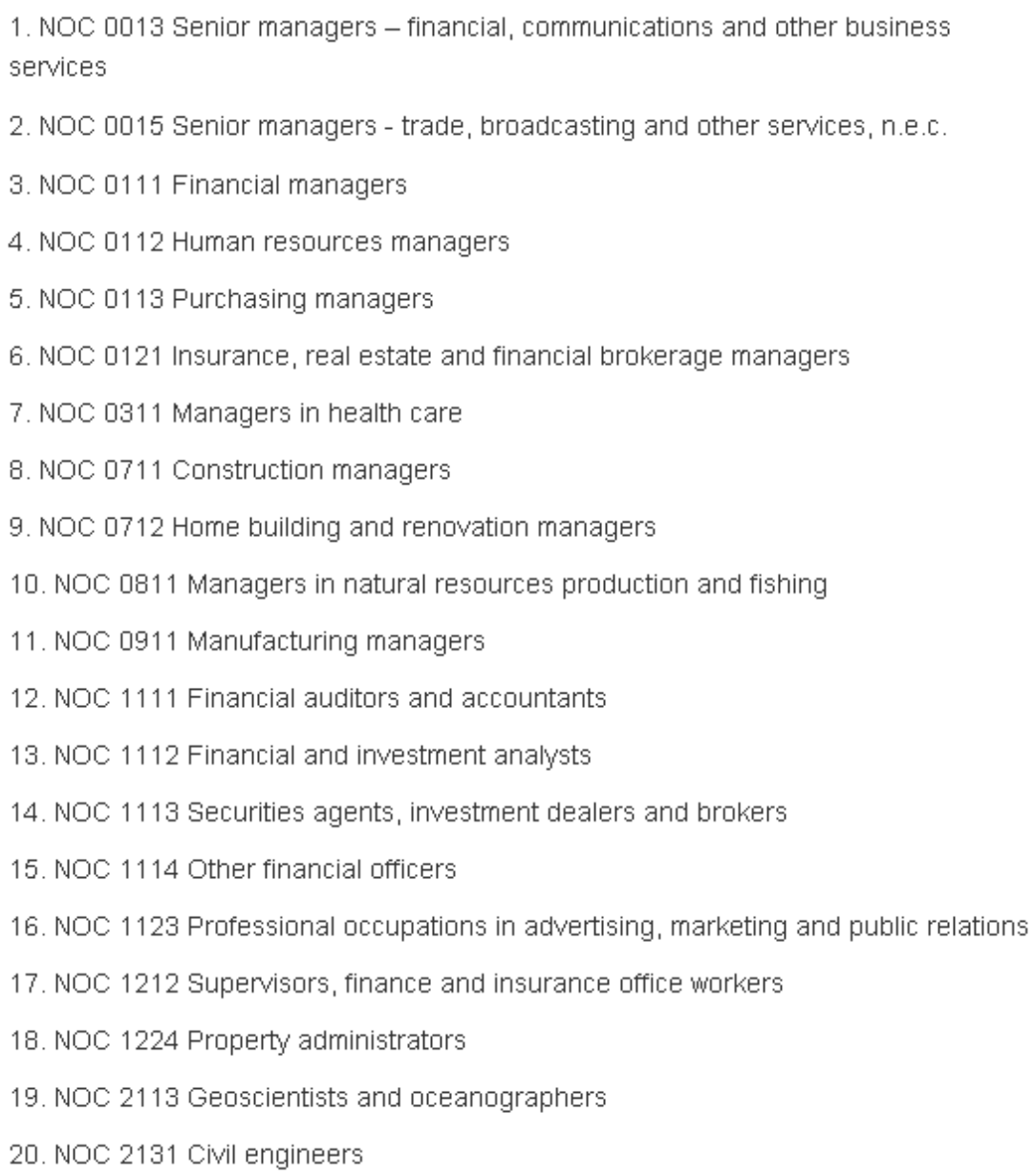

Figure 3 - List of deficit occupations in Canada, fragment (Source: Canadian Skilled Occupation List, 2015) 


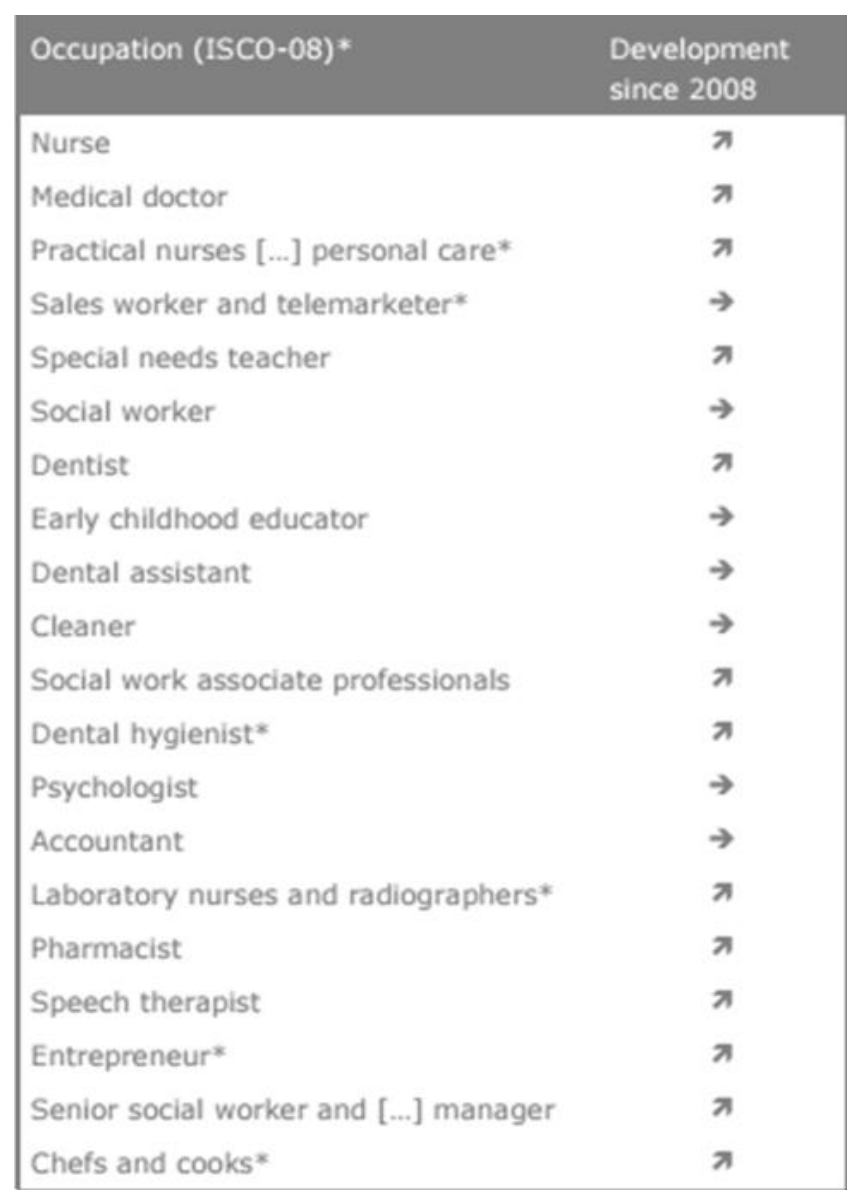

Figure 4 - List of deficit occupations in Finland, fragment (Source: Bottleneck Vacancies in Finland, 2013)

The Ministry of Employment and Economic Development of Finland publishes annually the list of the jobs most in demand as well as jobs which do not have such shortages (see Fig. 4 for a fragment). An important role in determining these lists is played by the Employment Service under the Ministry of Employment and Economic Development, which takes into account: employment perspectives, motivation, and inclination. If necessary, psychological testing and language tests are used to confirm the language skills of immigrants.

The Finnish list of designated occupations differs significantly from Australian and Canadian lists, since the former is oriented not only on attracting highly qualified labor force, but also on qualified workers who have elementary and secondary vocational education only (such as gardeners, social workers, accountants, cleaners, cooks, etc.). Fig. 4 proves that Finnish list is very much diverse in terms of education/qualification levels.

Therefore, we can conclude that it is necessary to take into account the following OECD member states' experiences while developing an optimal migration policy:

- implementing the principle of "integration upon arrival for migrants" (Finland);

- achieving balance at the labor market (Sweden, Denmark);

- granting a wide range of rights to migrants (Sweden, Finland); 


\section{STRATEGIES FOR EFFECTIVE ADAPTATION OF}

- reducing social tensions (Iceland);

- attracting highly skilled and qualified migrants (USA, Germany, Canada, Australia);

- developing and publishing the lists of jobs currently in shortage at the labor market (Australia, Canada, Finland).

\section{Labor migrants' adaptation in the OECD labor market: the case of bottleneck vacancies in Nordic countries, Baltic States and Central Eastern Europe}

This part of our article deals with the cases of bottleneck vacancies in Nordic countries, Baltic states and Central Eastern Europe as well as the analysis of migrants' employability and bottleneck vacancies' analysis in the regions in question. Data on migration trends, characteristics, institutions, traditions and employability is extremely important for both migration policy development and labor market regulation.

Demand for skills or immigrant labor does not guarantee an easy passage by default. Employability skills such as literacy and numeracy, technical skills, and good-quality personal skills (integrity, reliability, punctuality, learning capacity) are often in demand. According to the employers' surveys carried out by the ILO, the ETF, and Cedefop, "employability skills" rather than "the ability to do work well" are crucial at the OECD labor markets. We shall discuss some of the key drivers behind labor migration towards the OECD and underline certain challenges in relation to migration policy change.

There are significant differences between the OECD member states in terms of migrants' integration at the local labor markets. Certain countries have programmes and practices more relevant to migrants' integration and these apparently result in higher employment rates. Bottleneck vacancies analysis is often considered to be a good tool for migrants' integration at a labor market.

The data provided by the OECD has shown that migrant workers experience greatest difficulties with employability in such countries as Greece, Spain, and Portugal. Luxembourg and Germany appear to have the best migrant employment rates. This situation correlates with the general unemployment rates in these countries: high unemployment in Greece, Spain, and Portugal and much lower unemployment rates in Luxembourg and Germany. Thus, taking into account serious unemployment rate differences within the EU-10 (Austria, Belgium, Denmark, Finland, France, Germany, Luxembourg, the Netherlands, Sweden, the United Kingdom) and newer EU member countries, it would be plausible to state that due to poorer employment figures in Eastern and Western Europe, Western countries of the EU have been targeted by much larger migration inflows from the East. This is similar to developing countries in Asia and Africa. For instance, in 2013, developing Asian and African countries were the main migrant-sending countries. Such labor migration from poorer countries to more developed ones is likely to continue growing on all the continents. 


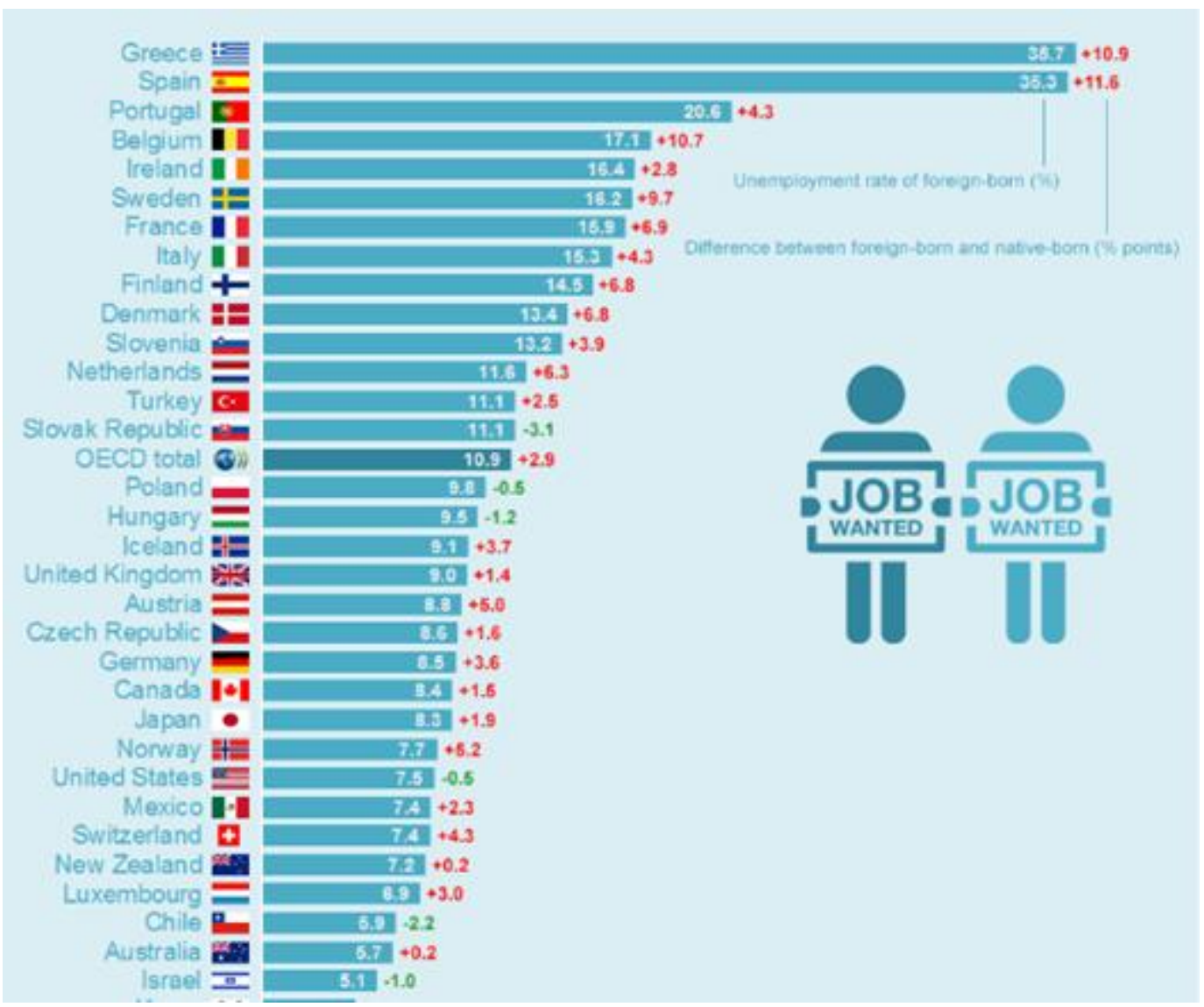

Figure 5- The rate of migrant and resident population employability in the OECD countries

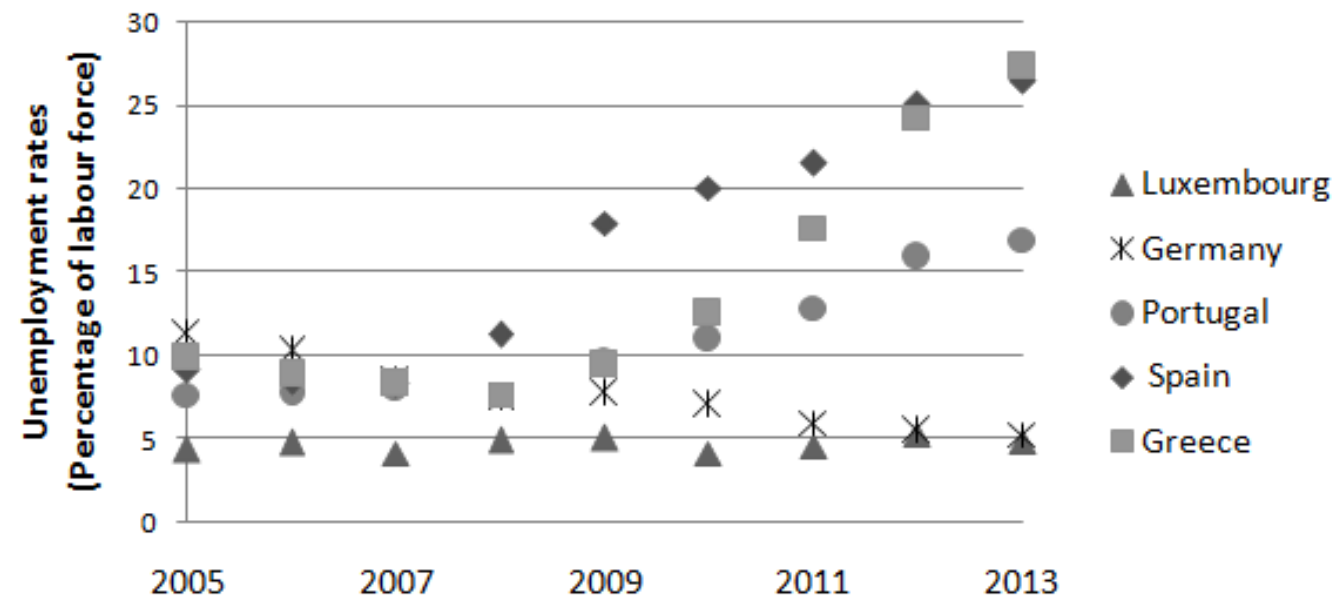

Figure 6 - Unemployment rates in the selected EU countries, 2005-2013

(Source: UNESCO Science Report) 


\section{STRATEGIES FOR EFFECTIVE ADAPTATION OF}

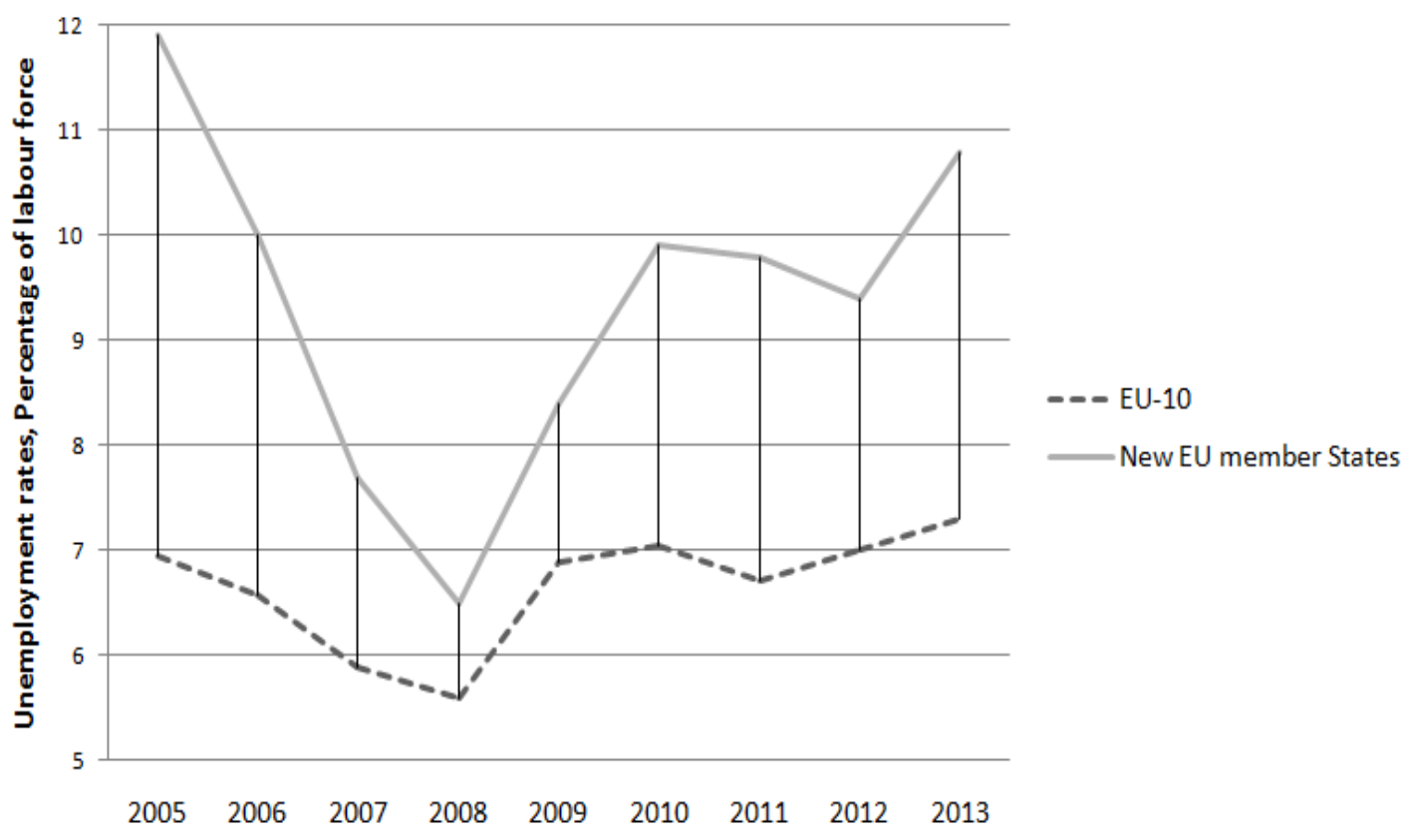

Figure 7 - Differences in unemployment rates between EU-10 and newer EU member states, 2005-2013

(Source: UNESCO Science Report)

Table 3 - GDPs of the selected receiving states and their volume of immigrants, data as of 2013

(Source: UNESCO Science Report)

\begin{tabular}{|c|c|c|}
\hline & $\begin{array}{c}\text { GDP according to } \\
\text { the IMF, bln \$, 2013 }\end{array}$ & $\begin{array}{c}\text { Number of migrants } \\
\text { according to UNESCO, } \\
\text { mln people, 2013 }\end{array}$ \\
\hline Germany & 3.610 & 9.8 \\
\hline France & 2.535 & 7.4 \\
\hline United Kingdom & 2.450 & 7.8 \\
\hline Spain & 1.523 & 6.5 \\
\hline
\end{tabular}

Economic differences are known to be the key drivers determining migration flows between countries. There were certain times, when immigrants were highly wanted. For example, in the post-war period, there was a considerable gap between unemployment rates in Western European receiving countries and sending countries. These countries invited temporary workers from Southern Europe, Turkey and the Maghreb to make up for the local workforce shortages. However, when the economy is not prospering, migrant workers become an easy target for discrimination as anti-immigration sentiment becomes significantly stronger, for a range of both economic and social reasons. The correlation between the level of a country's development measured by GDP volume and the number of 
migrants living in it is significantly high for such countries as Spain, the UK, France, and Germany (see Tab. 3 for more details).

Table 4 - Top-5 demanded occupations in the selected OECD member states

\begin{tabular}{|c|c|c|c|c|c|}
\hline$\#$ & Country & Occupations in demand & $\#$ & Country & $\begin{array}{c}\text { Occupations in } \\
\text { demand }\end{array}$ \\
\hline 1 & Finland & $\begin{array}{c}\text { Nurse } \\
\text { Social worker } \\
\text { Dentist } \\
\text { Preschool teacher } \\
\text { Psychologist }\end{array}$ & 7 & Norway & $\begin{array}{c}\text { Technician } \\
\text { Mountain metallurgy } \\
\text { technician } \\
\text { Truck driver } \\
\text { Industrial engineer } \\
\text { Chemical engineer } \\
\end{array}$ \\
\hline 2 & Sweden & $\begin{array}{c}\text { Mountain metallurgy } \\
\text { engineer } \\
\text { Crane operator } \\
\text { Geodesist } \\
\text { Software developer } \\
\text { Chemical engineer } \\
\end{array}$ & 8 & Denmark & $\begin{array}{l}\text { Electrical engineer } \\
\text { IT engineer } \\
\text { Software developer } \\
\text { Civil engineer } \\
\text { Engineer }\end{array}$ \\
\hline 3 & Slovakia & $\begin{array}{c}\text { Welder } \\
\text { Construction worker } \\
\text { Heavy industry } \\
\text { technician } \\
\text { Biotechnologist } \\
\text { Mechanic }\end{array}$ & 9 & Slovenia & $\begin{array}{c}\text { Welder } \\
\text { Truck and tractor unit driver } \\
\text { Processing industry } \\
\text { technician } \\
\text { Sales assistant } \\
\text { Bricklayer }\end{array}$ \\
\hline 4 & Hungary & $\begin{array}{c}\text { Nurse } \\
\text { Mechanical engineer } \\
\text { Doctor } \\
\text { Electrical engineer } \\
\text { IT developer } \\
\end{array}$ & 10 & Poland & $\begin{array}{c}\text { Welder } \\
\text { Locksmith } \\
\text { Bricklayer } \\
\text { Driver } \\
\text { Security guard } \\
\end{array}$ \\
\hline 5 & $\begin{array}{l}\text { Czech } \\
\text { Republic }\end{array}$ & $\begin{array}{c}\text { Cook } \\
\text { Technical } \\
\text { representative } \\
\text { Sales representative } \\
\text { Truck driver } \\
\text { Waiter } \\
\end{array}$ & 11 & Lithuania & $\begin{array}{c}\text { Sales manager } \\
\text { Accountant } \\
\text { IT specialist } \\
\text { Doctor (especially outside } \\
\text { big cities) } \\
\text { Needlewoman } \\
\end{array}$ \\
\hline 6 & Latvia & $\begin{array}{c}\text { Specialist in agriculture } \\
\text { Construction worker } \\
\text { Needlewoman } \\
\text { Long-vehicle driver } \\
\text { Packer }\end{array}$ & 12 & Estonia & $\begin{array}{c}\text { Electrician } \\
\text { Carpenter } \\
\text { Welder } \\
\text { Bricklayer } \\
\text { Plumber }\end{array}$ \\
\hline
\end{tabular}

The average wage in the migrant-sending countries usually does not exceed $20 \%$ of the corresponding amount in receiving countries (according to the International Labor Organization) which is an important driver in international labor migration. Furthermore, differences in quality of life, a measure reflecting overall well-being, in receiving and sending countries is also an important driver. 


\section{STRATEGIES FOR EFFECTIVE ADAPTATION OF}

Table 5 - Top-15 demanded occupations grouped by the levels of education

\begin{tabular}{|c|c|}
\hline $\begin{array}{c}\text { Higher vocational } \\
\text { education }\end{array}$ & $\begin{array}{c}\text { Secondary } \\
\text { vocational education }\end{array}$ \\
\hline Preschool teacher & Nurse \\
Psychologist & Social worker \\
Pharmacist & Dentist \\
Engineer & Excavator operator \\
Forest worker & Woodworking \\
Industry engineer & machine operator \\
Chemical engineer & Forestry worker \\
Mountain metallurgy & Technician \\
engineer & Mountain metallurgy \\
Geodesist & technician \\
Software developer & Truck driver \\
Electrical engineer & Crane operator \\
IT engineer & Welder \\
Civil engineer & Mechanic \\
Construction worker & Bricklayer \\
Heavy industry & Agricultural \\
technician & equipment mechanic \\
\hline
\end{tabular}

Thus, in this paper, we are offering some evidence to conclude (Tsapenko, 2009) that "the key drivers of migration are the gaps in economic development and corresponding standard and quality of life in sending and receiving countries".

Let us analyze 800 bottleneck vacancies (as of the EU Overview report: Mapping and Analysing Bottleneck Vacancies in EU labor Markets, 2014) according to the following criteria: States;

- Geographic - including Central and Eastern European countries, Nordic and Baltic

- Level of education - including higher vocational education (HVE) and secondary vocational education (SVE).

According to the EU Overview report "Mapping and Analysing Bottleneck Vacancies in EU Labor Markets" (2014), vacancies in various economic sectors do require different qualifications. Out of 800 vacancies reviewed in 12 OECD member-states, 600 vacancies were requiring higher vocational education and 200 were requiring secondary vocational education. As a result, the rankings of bottleneck vacancies for both higher and secondary vocational education in the OECD member states were developed (see Tab. 4 and 5).

Our bottleneck vacancies' analysis shows that specialists with higher vocational education and secondary vocational education are equally demanded in 12 selected OECD member states.

At the same time, specialists with secondary vocational education are more demanded in the Baltic States whereas those with higher vocational education are highly demanded in the Nordic countries where knowledge economy development is on the rise. In Central and 
Eastern European countries, such vacancies at the local labor market are rather balanced both specialists with secondary vocational education and specialists with higher education are needed.

In the course of bottleneck vacancies' analysis special emphasis should be made on high-tech/non-high-tech economic sectors. Vacancies demanded in high-tech economic sectors (235 vacancies with higher vocational education and 78 vacancies with secondary vocational education) are primarily represented by mountain metallurgy technicians, software developers, chemical engineers, mechanics, biotechnologists, heavy industry technicians, IT engineers, and electrical engineers. These vacancies are particularly demanded in Sweden, Denmark, Norway, Slovakia, and Hungary.

Non-high-tech bottleneck vacancies (365 vacancies with higher education and 122 vacancies with secondary vocational education) are represented in such economic sectors as construction, light industry, forestry, transportation and trade.

Medical staff vacancies (doctors, psychologists, pharmacists, nurses, dentists, social workers) are also in high demand. Healthcare specialists are primarily demanded in Finland, Hungary, and Lithuania. One possible reason for that could be rapidly ageing population in these countries resulting in higher demand for healthcare professionals. Vacancies in nonhigh-tech economic sectors are demanded in Latvia, Lithuania, Estonia as well as in Czech Republic and Slovenia.

Dissemination of information on the bottleneck vacancies analysis is highly important since it shall be applied for further analysis of current situation at the labor markets taking into account the actual foreign labor migration trends. Regularly updated data on bottleneck vacancies available for foreign labor migrants (on the example of the selected OECD member states) would contribute to much better understanding of both current and future potential labor market situations by all interested stakeholders. Experience and best practices of the selected OECD member states may become highly useful in searching for optimal solutions of the labor migration regulation issues.

\section{Conclusion}

The research made it possible to come to the conclusion that, in respect to foreign labor migrants in Finland, Sweden, Iceland, Canada, Australia, Denmark, the USA alongside with the Baltic States and the selected Central Eastern European countries effective measures have been systematically implemented for a relatively long period of time by now.

Migration policy in the abovementioned OECD member states is first of all aimed at the society's needs and thus results in negative factors' annihilation. A complex system of preventive measures is primarily aimed at migrants' integration into the receiving society, and these results in the OECD human capital development. A thoroughly planned system of different measures in their consecutive implementation includes migrants' adaptation in terms of culture and language and specificity of the local labor markets. It helps these countries overcome the present-day challenges: population ageing, depopulation, productivity gap.

High necessity of current transformations in the global migration policy is highly obvious taking into consideration, in particular, the already visible OECD experiences. It is obvious that full, valid, and up-to-date information on the labor market demands and necessities will contribute to much better result-oriented decision-making. Information 


\section{STRATEGIES FOR EFFECTIVE ADAPTATION OF}

collection on foreign labor migrants is clearly not enough, it is also important to use it for further analysis of the current situation at the labor market and in the consequent decisionmaking. The OECD experience might become highly useful in finding brand new solutions for successful regulation of the global foreign labor migration.

Thus, in order to develop an optimal migration policy, governments shall take into account different aspects of this policy implementation - education, training, innovations, workplace practices and relations, development of specific industries, etc. That is why the OECD annually develops a list of in-demand occupations along with the reference skills required for them. Despite the decades of harmonization efforts, there are still gaps in the OECD members' labor markets in terms of labor demand, employment and barriers. In our analysis, we have looked at some macroindicators and reviewed about 800 bottleneck vacancies to identify the differences across blocks of the OECD member-states, sectors and levels of education referring to skill levels in demand. There are huge gaps between Nordic states and more southern members of the OECD. Differences in the levels of economic development also seem to have their effect on labor demand in different countries.

Taking into account the existing OECD experiences in successful migrants' adaptation strategies, the following recommendations could be proposed on the global level:

1. Development of a comprehensive monitoring system over foreign labor migration should start with collection and processing of information from various sources (churches, mosques, statistical institutes, pension funds, tax services and so on). Information should be collected and analyzed by the most meaningful demographic parameters - age, gender, education level etc. Availability of complete, reliable and always up-to-date information would facilitate successful administrative decision-making in this field. These decisions shall include future migration flows planning depending on country's challenges and labor market situation.

2. Migration flows projection. Obviously, migration flows' projection today is the most important precondition for determining the future needs of the economy. Therefore, it is necessary to strengthen the labor market forecasting parameter which will be an important step towards more effective migration policy as well as social tension reduction.

3. It is highly recommended to approve, on the state level, a widely recognized principle of "integration before migration" through wider provision of additional information on culture and history of the receiving country, its specific features, realistic prospects and opportunities of all incoming people. Implementation of this principle as a fundamental one would create better conditions for migrants' integration into the local societies, and not as national diasporas, as it is currently the case in many countries receiving migration inflows.

4. Implementation of all these measures stemming from the best OECD practices would mitigate globally the situation with foreign labor migrants and shift the phenomenon of migration as such from the category of "threats" (to a country, society and/or local labor market) to the category of "opportunities" in terms of human potential development.

\section{References:}

Gatman, Ch. \& Schonberg, U. (2007). How general is human capital? A task-based approach. Available online at: http://www.cepr.org/meets/wkcn/4/4560/papers/GathmannFinal.pdf 
Gluschenko, G. \& Ponomaryov, V. (2009). Migration and Development. Moscow: Economica Publishing House.

Heikkilä, E. \& Pikkarainen, M. (2011). Internationalization of Population and labor Force from the Present to the Future in Finland. Available online at: http://www.aemi.dk/publications/AEMI\%20Journal\%2008-09.pdf?page=169

Indicators of immigrant integration. (2015). OECD, Available online at: http://www.oecd.org/els/indicators-of-immigrant-integration-2015-settling-in-9789264234024en.htm [accessed 24 August 2015].

International migration outlook. (2013). OECD, Available online at: http://static.pulso.cl/20130612/1768132.pdf

Lucas, R. (1987). On the mechanics of economic development. Available online at: http://www.parisschoolofeconomics.eu/docs/darcillonhibault/lucasmechanicseconomicgrowth. pdf

Mankiw, N., Romer, D. \& Weil, D. (1992). A contribution to the empirics of economic growth. Available online at: http://www.amenezes.uac.pt/macroeconomiaII/ macroeconomiaII_20062007/papers/mrw1992.pdf

Occupational Barometer in Finland.

(2015). https://www.europeanjobdays.eu/sites/default/files/EMD2015_21A1_1450_Finland_Occupati onal_Barometer_2015.pdf

Overview report: mapping and analyzing bottleneck vacancies in eu labor markets. All country fiches (2014). Available online at: http://ec.europa.eu/social/main.jsp?catId=993\&langId=en\&newsId=2131\&moreDocuments=ye s\&tableName=news

Pitukhina, M., Shabayeva, S. \& Privara, A. (2017). Cross-country analysis of neighboring migration policy by the example of Finland and Russia. Proceedings of ICEDU-2017. Malaysia. 17-28.

Pitukhina, M.A. \& Sigova, V. (2015). Keys to success: Finnish migration policy. Sociologicheskie issledovaniya. 4, 35-38.

Pitukhina, M. (2015). Migration processes in the contemporary world. Petrozavodsk: Petrozavodsk State University.

Russia and EU member states. (2011): Statistical book. Moscow: Rosstat.

Sassen, S. (1991). The Global City: New York, London, Tokyo. Princeton: Princeton University Press.

Tsapenko, I. (2009). Migration Management: Experience of Developed Countries. Moscow: Institute of World Economy and International Relations, RAS.

UN migration data. (2013). Available online at: http://esa.un.org/unmigration/TIMSO2013/migrantstocks2013.htm?msdo 


\section{STRATEGIES FOR EFFECTIVE ADAPTATION OF}

UN press release (2017). 232 million international migrants living abroad worldwide - new UN global migration statistics reveal. Available online at: www.un.org.internationalimigrantsworldwide_totals2013

World development report "mind, society, and behavior". (2015). Available online at: http://www.worldbank.org/en/publication/wdr2015

World economic situation and prospects. (2014). New York: United Nations publication

Paper submitted

Paper accepted for publishing

Paper published online
16 July 2020

07 September 2020

30 September 2020 